\title{
THE EFFECT OF THE COVID-19 PANDEMIC AND QUARANTINE RESTRICTIONS ON BUSINESS AND SOCIO-ECONOMIC DYNAMICS IN UKRAINE
}

\author{
Mariana Melnyk ${ }^{1}$, Iryna Leshchukh ${ }^{2}$, Viktoriia Baranova ${ }^{3}$ \\ ${ }^{1}$ D. Sc. (Econ.), Prof., Dolishniy Institute of Regional Research of NAS of Ukraine. \\ E-mail address: mar.melnyk@gmail.com
}

${ }^{2}$ Ph.D. (Econ.), Senior Researcher, Dolishniy Institute of Regional Research of NAS of Ukraine; 4 Kozelnytska Str., Lviv, 79026, Ukraine. E-mail address: ira_leschukh@ukr.net

${ }^{3}$ D. Sc. (Econ.), Prof., Odessa National Economic University. E-mail address: vgbaranova58@ gmail.com

Received 0109 2021; Accepted 05092021

\begin{abstract}
The goal of the present article is to provide a comprehensive study of the effect of the COVID-19 pandemic and quarantine restrictions on the business development and socio-economic dynamics in Ukraine. The key hypotheses of the research: 1) the COVID-19 pandemic and quarantine restrictions reduce the pace of macroeconomic development in Ukraine, this being manifested in the decrease in GDP, the scope of export-import operations as well as decline in industrial production; 2) reduced pace of macroeconomic development causes: 2.1) reduced economic mobility of economic entities; 2.2) negative social consequences manifested in reduced real income of residents, unemployment growth. The effect of specific factors of macroeconomic development and economic mobility of business entities on the unemployment rate increase in Ukraine has been shown through the correlation and regression analysis. Findings: Quarantine restrictions applied for the sake of slowing down the speed of the pandemic spread have acted as a factor causing decrease in GDP, scope of export-import operations as well as decline in the industrial production in Ukraine. It has been established that reduction of the pace of macroeconomic development in the background of unprecedented restrictive measures has caused economic imbalances in the country, manifested in inflation fluctuations and increase in the prices of foodstuffs and industrial goods, reduced business activity of business entities, decline in the commodity turnover volume, reduced business profitability. It is stressed that in the conditions of poor control over the processes of disease spread and uncertainty in the timeline of the pandemic the efficiency of the business activity stimulation in Ukraine can be ensured via consideration of the effects of behavioural economics as well as direction of the limited financial resources into the fields of the country's economy that can ensure its smart specialization and/or are building their capacity even under pandemic conditions.
\end{abstract}

Keywords: COVID-19 pandemic; Risks and Financial management, Business activity; Social effects of coronavirus; Economic effects of coronavirus; Business; Economics and Finance.

JEL Classification: $M 21, P 43, I 18$.

\section{Introduction}

The new strain of coronavirus COVID-19 - that broke out in Asia at the end of 2019 and very quickly grew into a pandemic, has come to be a new global challenge for the social and economic development of the countries of the world.

Global panic, hyper quick disease spread and lack of knowledge about the ways/methods of its treatment led to the quarantine announced in most countries of the world. As the result, a transport and logistics collapse occurred, production processes stopped for an indefinite period of time, and that caused a new financial and economic crisis. The global economic recession in the background of the COVID-19 pandemic laid

Copyright (C) 2021 Author(s), published by Vytautas Magnus University. This is an open access article distributed under the terms of the Creative Commons Attribution Non-Commercial 4.0 (CC BY-NC 4.0) license, which permits unrestricted use, distribution, and reproduction in any medium provided the original author and source are credited. The material cannot be used for commercial purposes. 
down the foundations for the slowdown in the Ukrainian economy as well (in the early 2020).

\section{Literature review}

Modern research of the effect of the COVID-19 pandemic on macroeconomic development and business activity can relatively be split into three contexts:

1) general assessment of global trends. For example, researchers Islam \& Muyeed (2020) have estimated that the crisis caused by the COVID-19 pandemic may cost the global economy 2.7 trillion USD. That makes some $3.06 \%$ of the global GDP.

The authors point to the need for the governments of the countries of the world as well as international organizations to take preventive steps to deescalate the negative effects of the pandemic. The threats for the global economy development in the coronavirus conditions, in particular, in the context of attainment of sustainable development goals, are also outlined in the researches by Ibn-Mohammed T., Mustapha K.B., etc. (2020). The authors substantiate the need for reconsidering the current global economic growth model in favour of circular economy activation.

The negative effect of coronavirus on the global social and economic development is also confirmed by the studies done by Pekhnyk \& Borzak (2020), Carlsson-Szlezak, Reeves \& Swartz (2020); Sikder, Zhang \& Ahmod (2020); Lenzen, Li, Malik, Pomponi et al. (2020). Along with that, the latter focus on availability of certain environmental benefits gained from the pandemic.

2) assessment of the effect on the development of specific types of economic activity. The most widespread in this context are the researches of the trends in the international trade, transport, and tourism. In particular, the effect of the pandemic on tourism and international air transportation is marked as catastrophic by Gössling, Scott \& Hall (2020), J. Liu and other (2020). In their scientific papers the authors call the effect of COVID-19 on the changes in the society, economy, and tourism similar to the effect of the current climate crisis and challenge the tourism growth model advocated by the leading global tourist organizations (UNWTO, ICAO, CLIA, WTTC, etc.).

The sensitivity of tourism and hospitality industry to global disasters, including COVID-19, is also stressed by Chang, McAleer \& Ramos (2020). Of interest are the researches by $\mathrm{X}$. Yang \& Wong (2020), who prove, on the basis of their own conceptual model, that traveling discrimination caused by the COVID-19 pandemic has a negative effect on tourists in the psychological context and intensifies their concerns.

3) analysis of the effect on the macroeconomic development and entrepreneurship by specific countries of the world (for example, Dankiewicz, Balawejder, Tomczyk \& Trynchuk (2021)). However, now there are almost no substantial studies of the effect of the COVID-19 pandemic and quarantine restrictions on the macroeconomic development and business activity in Ukraine yet. Thus, in some occasional papers by Ukrainian scientists (e.g. Birbirenko, Zhadanova and Banket, 2020, Vahner and Demko, 2020)) this issue is mainly considered only in the context of reduced business profitability (a purely economic aspect, where only companies act as business entities), while no attention is paid to the negative social consequences caused by the macroeconomic development decline (that is the dynamics of business activity of residents as economic entities is not considered or is considered only partially).

\section{Methodology}

The key hypotheses of the research are three assumptions about the effect of the COVID-19 pandemic and quarantine restrictions on business activity in Ukraine:

Hypothesis one. The COVID-19 pandemic and quarantine restrictions reduce the pace of macroeconomic development in Ukraine, this being manifested in the decrease in GDP, the scope of export-import operations as well as decline in industrial production. 


\section{Sciendo}

Management Theory and Studies for Rural Business and Infrastructure Development

eISSN 2345-0355. 2021. Vol. 43. No. 3: 415-429

Article DOI: https://doi.org/10.15544/mts.2021.38

Hypothesis two. Reduced pace of macroeconomic development causes:

first, reduced economic mobility of economic entities, manifested in the inflation fluctuations and increase in the prices of foodstuffs and industrial goods, reduced business activity of business entities, decline in the commodity turnover volume, reduced business profitability;

second, negative social consequences manifested in reduced real income of residents, unemployment growth.

The authors have used the following methods for checking the hypotheses: logical generalization, systemic analysis, comparison and synthesis, economic and statistical as well as factor analysis, economic and mathematic simulation, graphic analysis, correlation and regression analysis.

\section{Results}

To counteract the spread of COVID-19 Ukraine has applied the following:

- active quarantine restrictions (the so called rigid quarantine) - from March 12, 2020 to May 25, 2020;

- adaptive (a bit eased up) quarantine - since May 25, 2020. Its "rigidity" was determined by the epidemic situation in a specific region of the country; The Government developed a 5-stage plan of the country's exiting the quarantine starting with the end of May;

- active quarantine restrictions (rigid quarantine) - from January 08, 2021 to
January 24, 2021 (the period of New Year and Christmas holidays).

\section{Hypothesis testing.}

1.Hypothesis one. The quarantine restrictions applied worked, on the one hand, as the factor slowing down the pandemic spread, while, on the other hand, caused drastic slowdown of the pace of economic development of Ukraine, manifested primarily via:

1.1.GDP decrease. Starting with 2016 Ukraine's economy, in spite of availability of geopolitical risks and threats caused by the conflict with the Russian Federation overcame the manifestations of the crisis and moved over to the phase of gradual economic recovery over 2016-2019. On average, real GDP for that period was growing by $3 \%$. However, in the Ist quarter of 2020 the above indicator went down, as compared to the respective period of 2019 , by $1.3 \%$, and in the IInd quarter - by the record $11.4 \%$ (867.8 bln. UAH against $932.7 \mathrm{bln}$. UAH; fig. 1). That is what the introduction of rigid quarantine restrictions in March-May 2020 to counteract the spread of COVID-19 resulted in. To compare, the GDP fall in the IInd quarter of 2020, as compared with the respective period of 2019, made: in Spain - 22.1\%; France 19.3; Austria - 12.8; Germany - 11.7\%; Lithuania $-3.8 \%$ (source: The forecast of economic and social development of Ukraine for 2021-2023). 


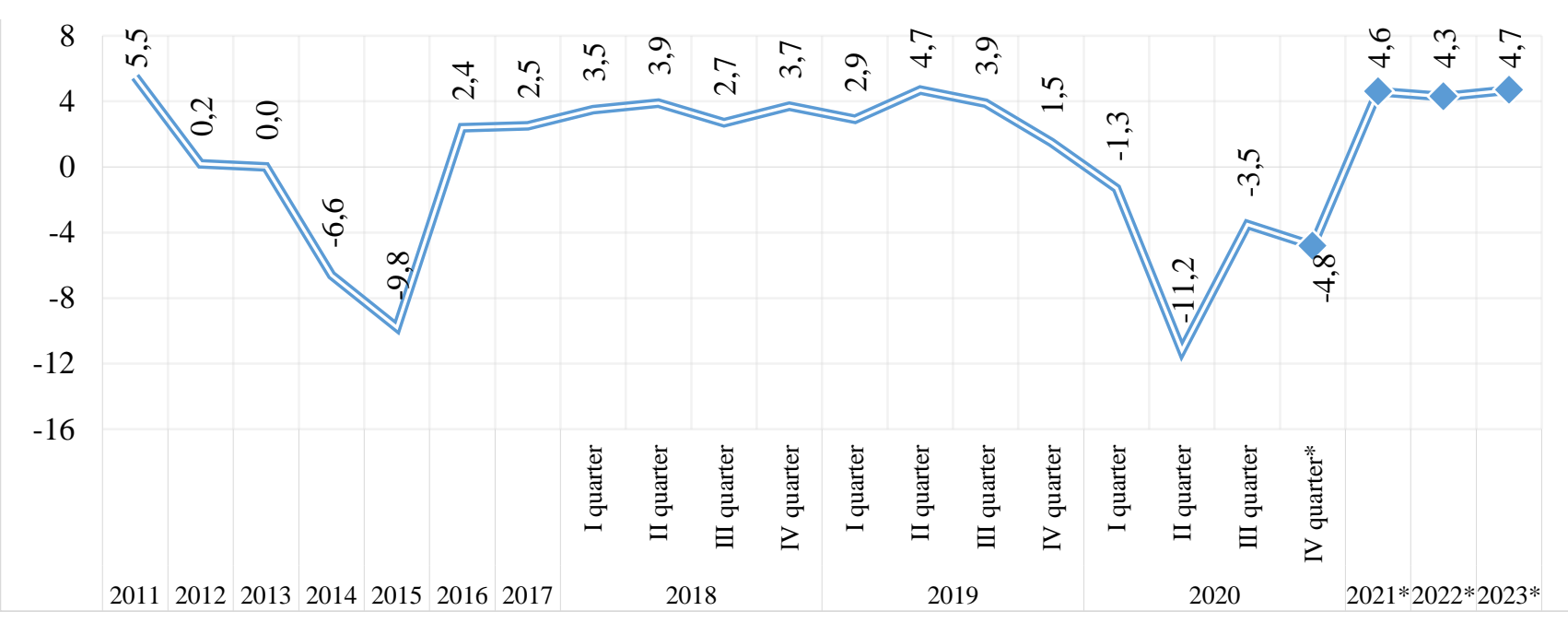

Figure 1. The change of real GDP, 2011-IIIrd quarter of $2020, \%$ to the respective quarter of the previous year

Source: compiled by the authors on the basis of data from the State Statistics Service of Ukraine

*Forecast indicators of the National Bank of Ukraine

Some easing up of the quarantine restrictions in the late May 2020 contributed to the decrease in the real GDP contraction in the IIIrd quarter to $3.5 \%$. The highest pace of GDP contraction as of September 2020 was recorded in the following types of economic activity:

- provision of other services, including activity of households $(-25.1 \%$ to the respective quarter of 2019);

- temporary accommodation and meals organization $(-17.9 \%$ to the respective quarter of 2019);

- activity in the field of administrative and auxiliary servicing $(-12.1 \%$ to the respective quarter of 2019).

Along with that, the forecasts for the pace of the real GDP contraction in Ukraine, based on the year 2020, differ: $-7.7 \%$ (International Monetary Fund); -6\% (National Bank of Ukraine) (Zhalilo et al. (2020)); $3.5 \%$ (World Bank) (Kulytskyi (2020)); $4.8 \%$ (Ministry of Economic Development, Trade and Agriculture of Ukraine) (source: The forecast of economic and social development of Ukraine for 2021-2023).

Instead, the forecast of the profile Ministry concerning the real GDP volume in 2021-2023 is rather optimistic. Thus, the above indicator is expected to grow in 2021 by $4.6 \%$, in 2022 - by $4.3 \%$, and in 2023 - by
4.7\% (source: The forecast of economic and social development of Ukraine for 20212023). More restrained is the forecast of the National Bank of Ukraine. Thus, real GDP contraction in the Ist quarter of 2021 by $1.9 \%$ as compared to the respective period of 2020 is made up for by its gradual growth in the following quarters. Thus, it expects the annual real GDP growth by $4.2 \%$, and in 2022 - by $3.8 \%$ (source: The National Bank of Ukraine). And the International Monetary Fund forecasts the growth of Ukrainian GDP for 2021 at the rate of $5.8 \%$ (source: The effect of the crisis caused by the coronavirus pandemic will be felt until 2025).

1.2.Reduced volume of export-import operations. The effect of the global recession resulting from the COVID-19 pandemic on Ukraine's export opportunities at the beginning of the coronacrisis was relatively small. In March and April of 2020 the volume of Ukraine's commodity export was only 4.2 and $6.1 \%$ lower than in March and April of 2019 , respectively. Still, that happened in the background of reduction of the share of capital-intensive and technological fields in the commodity export structure (metallurgy and engineering) as well as increased amount of raw materials (agriculture, mining) and low-tech (food industry) productions. However, already in May, as the result of 
reduced foreign investment and consumer demand in the core countries-trade partners as well as due to the effect of internal restrictions set for economic activity, the volume of commodity export went down by $24.2 \%$ as compared to the respective month of 2019. In May all commodity groups of export experienced a decrease (Zhalilo et al. (2020)).

April and May of 2020 became the period of the peak fall in the volume of import operations (respectively, $26.7 \%$ and $30.5 \%$ compared with the same month of the previous year), this being caused by reduced demand for consumer and investment products in Ukraine.

However, a more considerable decrease of the volume of import of goods and services to Ukraine, as compared to export of goods and services from Ukraine over JanuaryAugust 2020, finally led to the positive balance of foreign economic activity in the country as of the end of the IInd quarter of 2020 (1,078.5 mln. USD; fig. 2). And the factor of import coverage by export in January-November 2020 made 0.92 (in January-November $2019-0.83$ ).

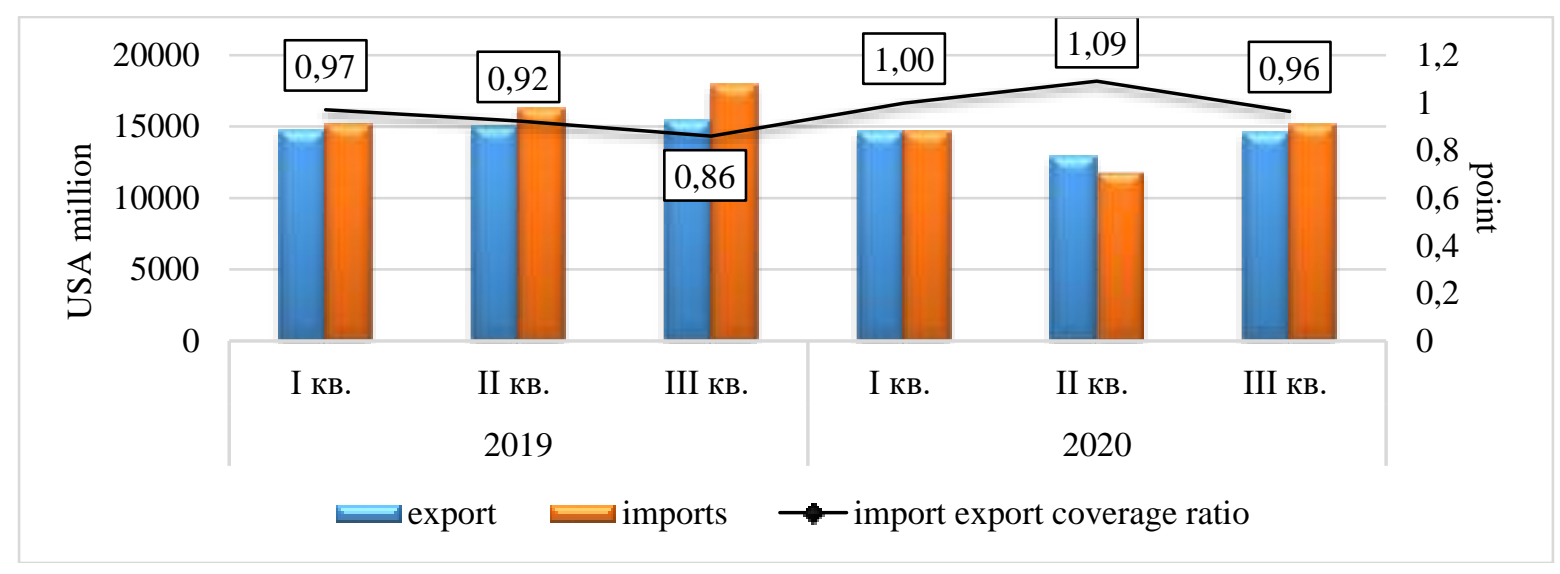

Figure 2. Foreign trade balance of Ukraine, Ist-IIIrd quarters of 2019 and Ist-IIIrd quarters of 2020

*Source: compiled by the authors on the basis of data from the State Statistics Service of Ukraine

In our opinion, rather optimistic, on the one hand, and not likely, on the other hand, is the forecast for the status of foreign economic activity in Ukraine for the nearest future. Thus, according to the data of the National Bank of Ukraine, in spite of the drastic reduction in the volume of export-import operations in 2020, already in 2021 the respective figures will get back to the precrisis mark, while the index of import coverage by export will make some $85 \%$, the same as in 2019 (source: The National Bank of Ukraine).

1.3.Decline in industrial production. In January-November 2020 industrial production fell by $6.2 \%$ as compared to the respective period of 2019, while the index of processing industry products made $92.2 \%$ against the respective period of the previous year.

The processing industry underwent the most significant losses, in particular, over March-May, in the period of the rigid quarantine in Ukraine. Instead, over that period pharmaceutical production gained positive dynamics (fig. 3), which fact is caused not that much by the increased COVID-19 rate in the Ist-IInd quarter of $2020^{1}$ but by the panic around the pandemic, created in the country artificially and

\footnotetext{
1 The average number of people falling ill per week in March-May varied from 9 to 474 (according to the data of Rating. Business in Official Figures. URL: https://q.rating.zone/; date of address: January 2021).
} 
"supported" by the global coronavirus depression.

Further growth in the scope of production in the pharmaceutical industry in August 2020 resulted from the statements made by the Government and the President of Ukraine (in July) concerning the country's being on the verge of the "second wave" of COVID-19. In general, the Ministry of Economic Development, Trade and Agriculture of Ukraine forecasts pharmaceutical production growth by the outcomes of the year 2020 by $4.6 \%$ as compared to the previous year(source: The forecast of economic and social development of Ukraine for 2021-2023).

\section{Hypothesis two - the consequences} of business activity reduction in Ukraine.

Reduction of macroeconomic dynamics in Ukraine in the background of rapid development of the COVID-19 pandemic, together with the application of unprecedented restriction measures, caused social and economic crisis in the country.

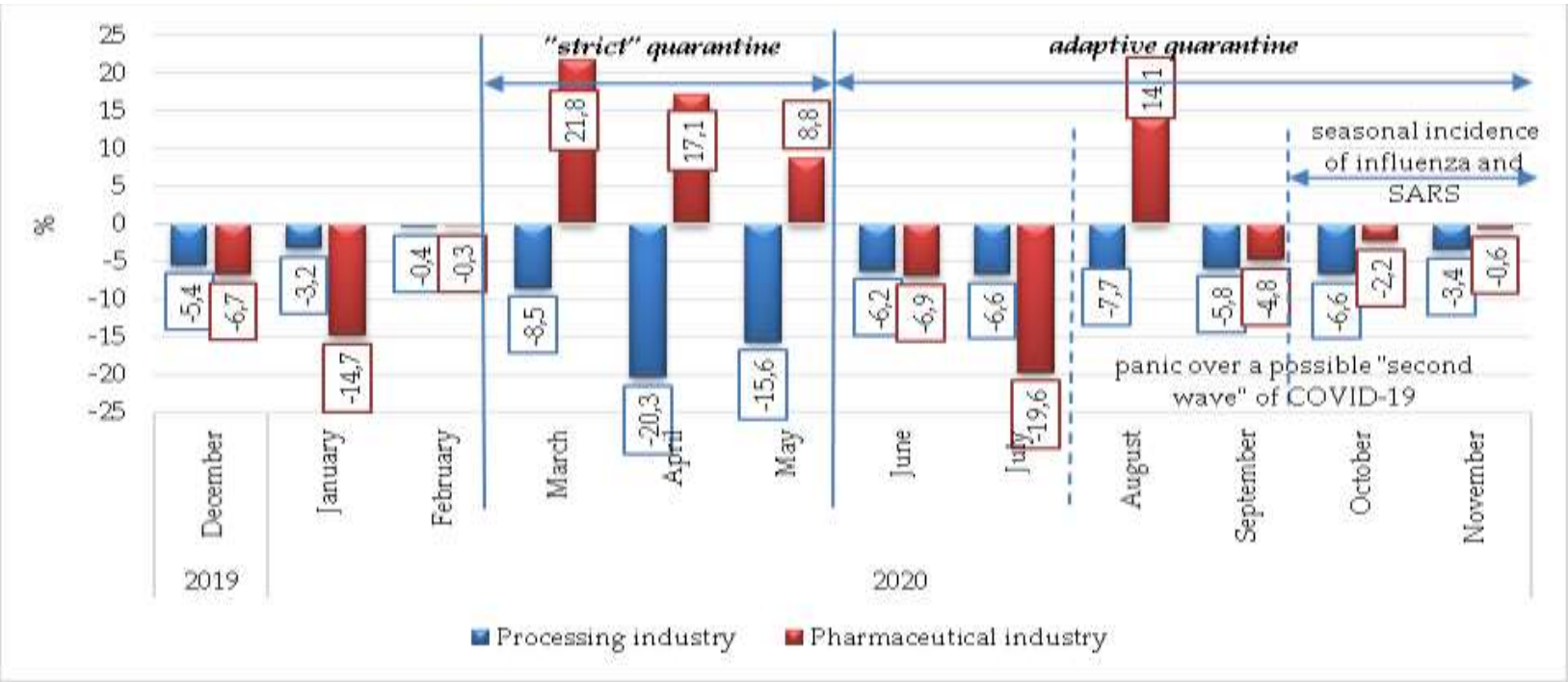

Figure 3. Industrial produce dynamics, \% against the respective month of the previous year *Source: compiled by the authors on the basis of data from the State Statistics Service of Ukraine

\subsection{Economic dimension. Introduction} of a ban on the work of shopping and leisure centres, catering institutions, institutions of the tourist and hotel infrastructure, trade and public servicing of residents, limitations in transport operation, etc. have led to the following:
Inflation fluctuations. Inflation in the consumer market as of November 2020 as compared to October 2020 made $1.3 \%$, and since the beginning of the year $-4.1 \%$. Basic inflation rate in November 2020 as compared to October 2020 made $0.7 \%$, and since the beginning of the year $-4.2 \%$ (Fig. 4). 


\section{Sciendo}

Management Theory and Studies for Rural Business and Infrastructure Development eISSN 2345-0355. 2021. Vol. 43. No. 3: 415-429

Article DOI: https://doi.org/10.15544/mts.2021.38

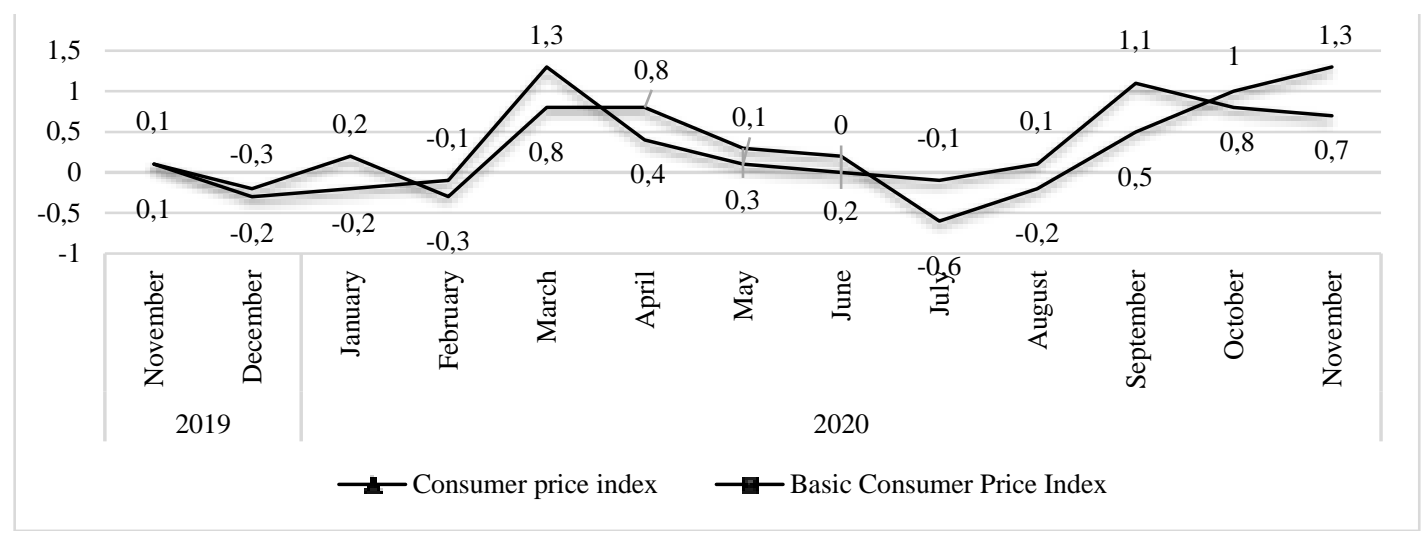

Figure 4. The core inflation trend, $\%$ to the previous month

*Source: compiled by the authors on the basis of data from the State Statistics Service of Ukraine

Respectively, fluctuations in the prices of goods and services were also quite substantial, and this was most noticeable in the first weeks after the quarantine restrictions were introduced. In the background of the speculative demand in April the prices of foodstuffs and non-alcoholic beverages increased by $2.1 \%$ as compared to the previous month. Also, the prices of essential goods and goods with antiseptic properties like lemons, garlic, and onion were rapidly going up. The prices of vegetables with a rather long shelf life were also going up at a higher pace: potato, carrot, etc. Such rise was caused not just by the rising consumer demand, but by the problems with logistics in the background of transport limitations as well.

Easing up of hryvnia in March also affected fluctuations in commodity prices. As the result, goods represented mainly by imported products or having a high share of import in their prime cost were also rising in price. In particular, the prices of small household appliances and pharmaceuticals quickly reacted to hryvnia devaluation. The speculative demand resulting from the fear of facing the deficit of these goods or their further getting more expensive contributed to the price rise. However, already starting with April the price rise pace got lower, and the prices of some goods even went down (source: The National Bank of Ukraine).
The prices of services over the period of effect of the quarantine restrictions showed blended dynamics. Thus, for example, while in January-May 2020 the cost of food delivery from restaurants almost did not change, after the quarantine prolongation and expansion of the demand for those services their cost started rising.

Reduction of business activity of companies (slowdown in the pace of new company establishment). The decline in business activity in Ukraine is proven by the fact that the speed of new company establishment in the Ist-IInd quarter of 2020 went down as compared to the similar period of the previous year, by $54.7 \%$. Thus, while in 2019, according to the data of the Unified State Register of Enterprises and Organizations of Ukraine over the above period 5,452 new companies had been established, in the reporting period only 2,471 companies were established. And in the period of rigid quarantine up to 50 companies were closed a day (source: Pharma - the premier violin of the quarantine). That proved considerable reduction of optimism and deterioration in the expectations of prospective entrepreneurs concerning new businesses, absence of startup capital due to reduction of savings that had been spent during the quarantine. Besides that, the respective trend may testify to the shifting of business activity into shadow activity, which fact also has a negative effect on the dynamics 
of the economy in general (Zhalilo et al. (2020)).

However, due to much more closer attention paid by residents to the condition of their health and disease prevention, increased demand for goods and services of the pharmaceutical industry, there has taken place a considerable growth in the number of newly established companies in the market of medical servicing and pharmacological products. The leaders here were enterprises (normally, not large by size) the core activity of which was as follows (source: Pharma the premier violin of the quarantine):

- production of pharmaceutical products and materials $(+600 \%$ as compared to the IstIInd quarter of 2019);

- extraction of mineral raw materials for the chemical industry as well as production of mineral fertilizers $(+100 \%$ as compared to the Ist-IInd quarter of 2019).
Reduced volume of goods and services sales. Besides reduced purchasing power of residents, narrowing down of the consumption of "non-essential" goods and services for precaution motives in the background of increased economic and epidemiological uncertainty as well as panic and uncertainty of the population about the nearest future came as the factors causing reduced volume of goods and services sales in Ukraine.

Rigid epidemic-related restrictive measures led to the rapid reduction in the volume of retail trade turnover (Fig. 5), which was particularly felt in the conditions of the rigid quarantine (Ist-IInd quarter of 2020) as the result of introduction of restrictions in the work of trade centers, large supermarkets, markets, etc.

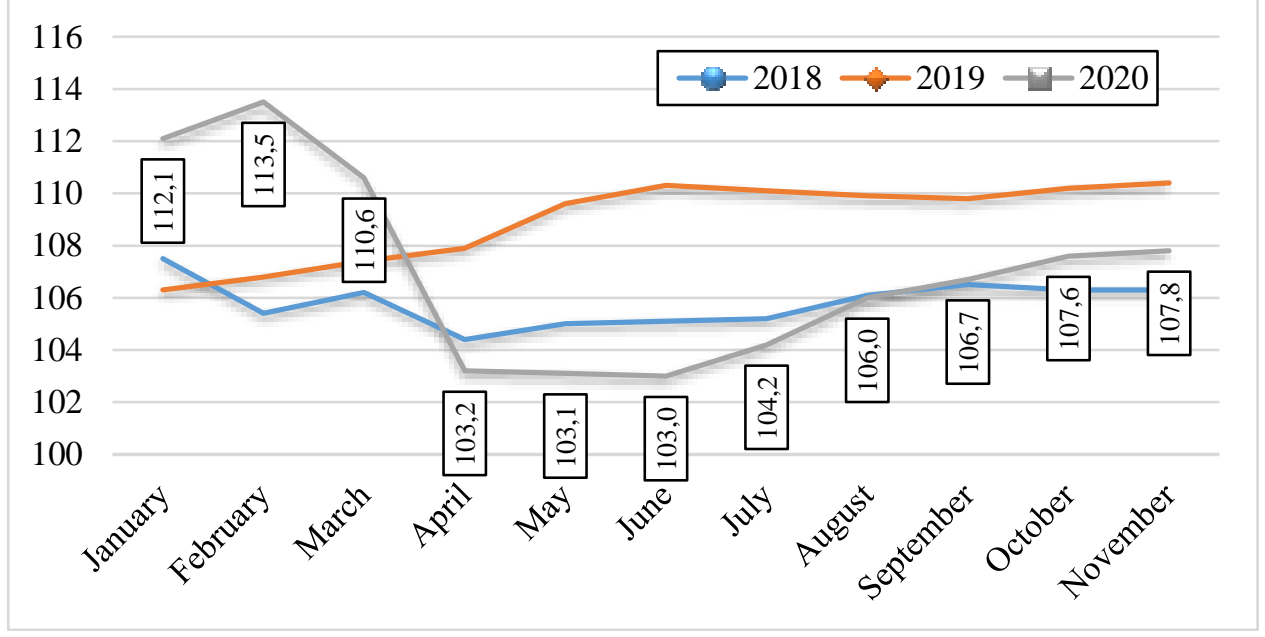

\section{Figure 5. The indices of physical retail trade turnover volume, $\%$ to the respective period of the previous year, on an accrual basis \\ *Source: compiled by the authors on the basis of data from the State Statistics Service of Ukraine}

Due to forced closure of offline shops, retail operators had to switch to working in the online mode. However, even with those out of them who had been actively developing their Internet sales before, the number of clients in the period of the rigid quarantine fell drastically by $30-70 \%$ (source: Retail during and after the quarantine).
However, restoration of the demand among residents in the background of improved consumer moods and salary increase as well as restoration of the work of shops and markets in the IInd half of 2020 caused some slowdown of the retail trade decline. 


\section{Sciendo}

\section{Management Theory and Studies for Rural Business and Infrastructure Development eISSN 2345-0355. 2021. Vol. 43. No. 3: 415-429 \\ Article DOI: https://doi.org/10.15544/mts.2021.38}

Reduction in the services sales volume was caused by reduced or unavailable offer of some types of activity affected by the quarantine restrictions the most. These are primarily the services of tourist agencies and tour operators, temporary accommodation and catering, cultural and mass as well as sports facilities, passenger transport (Fig. 6).

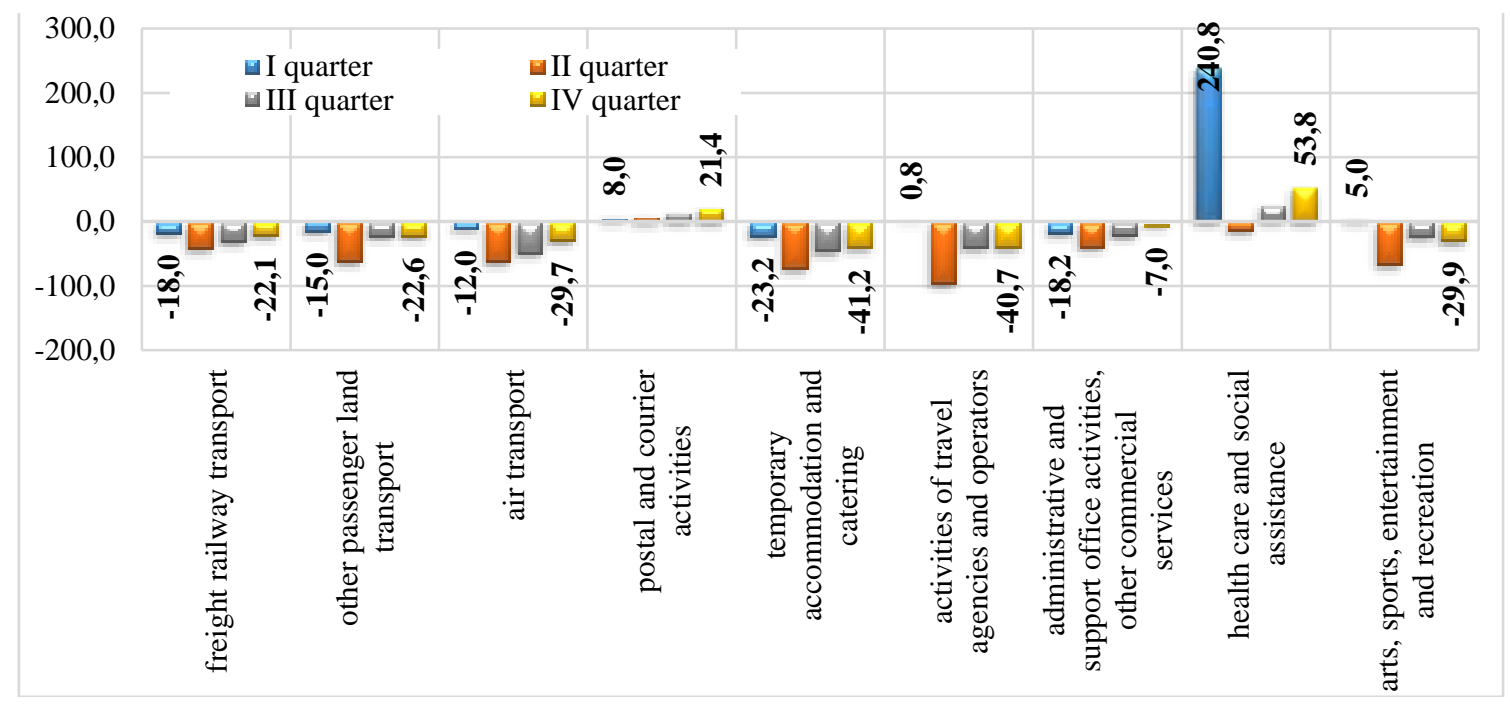

Figure 6. Dynamics of the volume of services sold by specific types of economic activity, \% to the respective month of the previous year

*Source: compiled by the authors on the basis of data from the State Statistics Service of Ukraine

Instead, as it can be seen from Fig. 6, the effect of the quarantine measures mainly had a positive impact on the work of postal and courier services in Ukraine. Thus, company "Nova Poshta" delivered three times more parcels and freights in the Ist half-year of 2020 than over the same period of the previous year. And in the IInd quarter of 2020 , in the peak of the quarantine, the volume of courier delivery increased by $35 \%$. Besides that, the figures for international delivery also raised twice over the above period (source: The effect of COVID-19 and quarantine restrictions on the Ukrainian economy).

Particularly popular in the quarantine was medicine delivery by mail, distance (online) sales of which became possible as the result of the respective permission given by the Cabinet of Ministers of Ukraine in April 2020 (the permission is valid over the quarantine period) (source: The Government has allowed distance selling of medicines).
Reduced profitability of doing business; pessimistic business moods as far as the results of their economic activity in the quarantine conditions are concerned. According to the data of the National Bank of Ukraine, the expectations of the country's businesses as to their business activity over the whole period the quarantine restrictions were in effect were under the equilibrium value (that is <50 points; Fig.7). And the most pessimistic were the expectations of the enterprises of the field of services (in April 2020 - only 20.4 points).

While in April-May (in the rigid quarantine period) the main concerns of business were related to reduced prices of goods of own production and services, already at the end of 2020, in the background of the lockdown expectations in January 2021, the companies in all sectors of the economy forecasted the rise of prices of ownproduced goods (expecting the rise of the prices of raw materials and materials) as well 
as decrease in the number of employees of their companies in the nearest future. The biggest redundancy may occur in construction companies, the trend of business expectations of which is still determined by the seasonal decrease in economic activity and narrowing down of the investment demand.

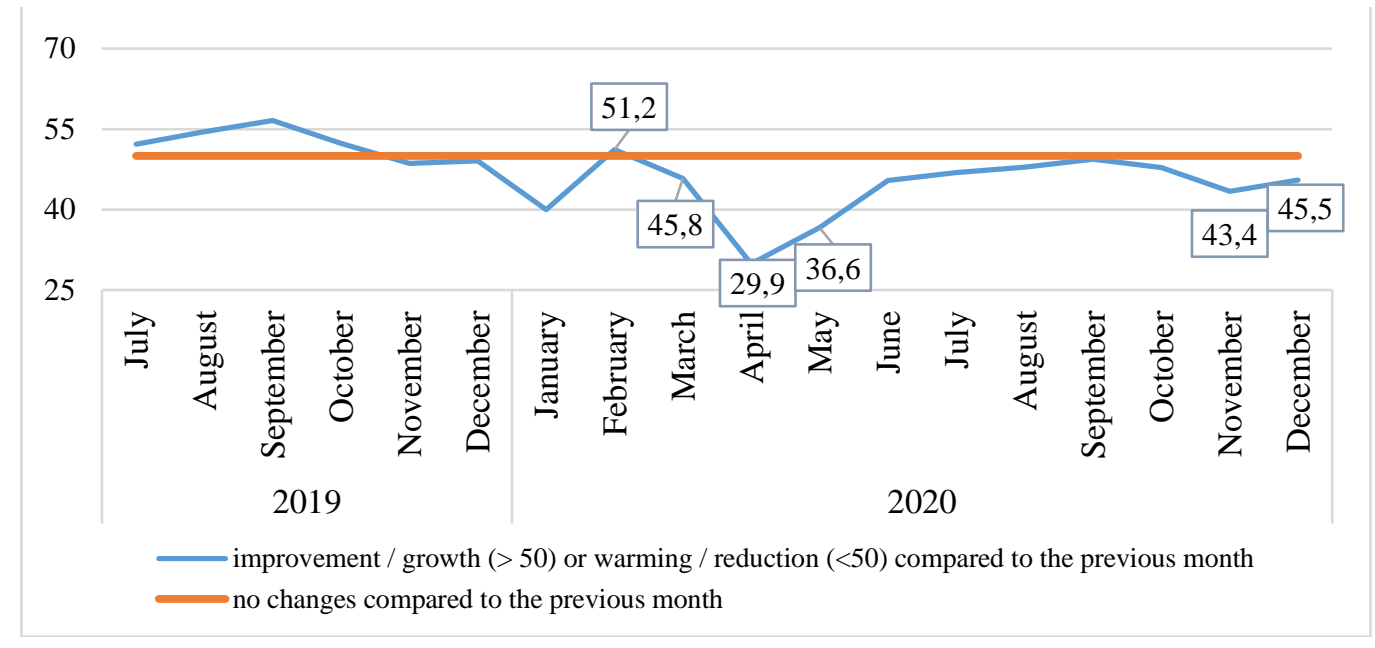

Figure 7. The index of business activity expectations of Ukrainian enterprises, points * Source: compiled by the authors on the basis of the materials of the National Bank of Ukraine

A considerable reduction of the volume of production and sales, demand weakening, transition to distance forms of employment and transition of employees into the standstill retime, among other things, have caused an increase in the share of unprofitable companies out of their overall number. In particular, in the IInd quarter of 2020 almost $76 \%$ of medium-sized and large companies of the hospitality industry, $69 \%$ of companies providing sports services, entertainment and leisure services as well as $60.7 \%$ of companies carrying out their activity in the field of real estate were unprofitable. And in the monetary equivalent in the Ist-IIIrd quarter of 2020, as compared to the similar period of 2019, medium-sized and large industrial companies, companies of the hospitality industry, wholesale and retail trade suffered the biggest losses (Table 1). 
Table 1. Pre-tax financial result for large and medium-sized companies by the types of economic activity in 2019-2020, mln. UAH

\begin{tabular}{|c|c|c|c|c|c|c|c|c|c|}
\hline \multirow{2}{*}{ Types of economic activity } & \multicolumn{3}{|c|}{2019} & \multicolumn{3}{|c|}{2020} & \multicolumn{3}{|c|}{ Change, UAH million, 2020 to 2019} \\
\hline & I quarter & II quarter & III quarter & I quarter & II quarter & III quartes & I quarter & II quarter & III quarter \\
\hline Total & \begin{tabular}{|l|}
111089,2 \\
\end{tabular} & 107004,6 & 124715,7 & $-4902,6$ & 34090,6 & 64130 & ת-115991,8 & $\sqrt{7}-72914$ & $\sqrt{ }-60585,7$ \\
\hline Agriculture, forestry and fisheries & 21 & \begin{tabular}{|c|}
$-44,7$ \\
\end{tabular} & $-19,6$ & $-158,7$ & 10,1 & 55,8 & $-179,7$ & ث 54,8 & 金 75,4 \\
\hline Industry & 41658,7 & 45021,9 & 68715,3 & $-66115,4$ & 25894,4 & $-4635,9$ & ת-107774,1 & $\sqrt{-19127,5}$ & $\sqrt{2}-73351,2$ \\
\hline Construction & 966,9 & 373,9 & 2297,5 & $-701,1$ & 1190,9 & 1139,1 & ᄀ -1668 & 勻 817 & ᄀ-1158,4 \\
\hline $\begin{array}{l}\text { Wholesale and retail trade; repair } \\
\text { of motor vehicles and motorcycles }\end{array}$ & 14611 & 22718,2 & 28270,8 & $-10952,8$ & 15108,3 & 8357,2 & $-25563,8$ & ₹ $-7609,9$ & ת-19913,6 \\
\hline $\begin{array}{l}\text { Transport, warehousing, postal } \\
\text { and courier activities }\end{array}$ & $-534,2$ & 369,7 & 8336,4 & $-27747,5$ & 7262,4 & 5596,8 & $\sqrt{-27213,3}$ & ثि 6892,7 & $\sqrt{ }-2739,6$ \\
\hline $\begin{array}{l}\text { Temporary accommodation and } \\
\text { catering }\end{array}$ & 332,4 & 747,2 & 1524,2 & $-2226,2$ & 242,8 & $-905,7$ & $-2558,6$ & $\S-504,4$ & $\S-2429,9$ \\
\hline $\begin{array}{l}\text { Information and } \\
\text { telecommunications }\end{array}$ & 5186,8 & 5425,5 & 6328,6 & 326,3 & 5226,6 & 4734 & $\sqrt{n}-4860,5$ & $\sqrt{ }-198,9$ & $\S-1594,6$ \\
\hline Financial and insurance activities & 22584,6 & 21504,9 & 2179,1 & 112530,3 & $-2200,7$ & 54811,1 & 산 89945,7 & $\sqrt{-23705,6}$ & 个 52632 \\
\hline Real estate transactions & 2132,9 & 3368,8 & 5518,9 & $-9309,3$ & 4218,3 & $-2804,8$ & - $-11442,2$ & ث 849,5 & ᄀ $-8323,7$ \\
\hline $\begin{array}{l}\text { Professional, scientific and } \\
\text { technical activities }\end{array}$ & 23521,1 & 7523,7 & $-1039,2$ & 1538,2 & $-23357,3$ & $-2432,4$ & ᄀ $-21982,9$ & $\sqrt{ }-30881$ & \-1393,2 \\
\hline $\begin{array}{l}\text { Activities in the field of } \\
\text { administrative and support } \\
\text { services }\end{array}$ & 599,6 & 645,8 & 1055,1 & $-956,2$ & 873,5 & 198,8 & ᄀ $-1555,8$ & 全 227,7 & $-856,3$ \\
\hline Education & $-0,2$ & $-2,4$ & $-0,1$ & $-34,2$ & $-1,9$ & $-31,8$ & $\begin{array}{ll}-34 \\
-1\end{array}$ & 金 0,5 & $-31,7$ \\
\hline Health care and social assistance & 101,5 & 68,2 & 208,9 & $-470,1$ & 484,7 & 821,3 & $\Omega-571,6$ & ثि 416,5 & 个 612,4 \\
\hline $\begin{array}{l}\text { Arts, sports, entertainment and } \\
\text { recreation }\end{array}$ & $-93,3$ & $-715,1$ & 1225,3 & $-623,6$ & $-875,3$ & $-761,5$ & $\Omega-530,3$ & $\sqrt{ }-160,2$ & $\sqrt{ }-1986,8$ \\
\hline Provision of other types of services & 0,4 & -1 & 114,5 & $-2,3$ & 13,8 & -12 & $\begin{array}{ll}\Omega & -2,7\end{array}$ & 14,8 & $\sqrt{2}-126,5$ \\
\hline
\end{tabular}

*Source: compiled by the authors on the basis of data from the State Statistics Service of Ukraine

Transport companies, primarily the ones carrying out passenger transportations, suffered great profit losses. For example, passenger transportations by the railway were completely stopped since March 11, 2020, and partially restored in the second half of May. In the conditions of the quarantine easing up the number of designated trains considerably went down, while the tickets for those trains were sold only for a limited number of seats in the carriages $(50 \%$ of seats). Hence, experts assess the losses of the Joint-Stock Company "Ukrzaliznytsia" at about $1 \mathrm{bln}$. UAH. And the losses of the air passenger transport by the results of 2020 may well reach 10-15 bln. UAH, and air companies can be expected to exit the crisis no sooner than in 2021-2022 (source: The effect of COVID-19 and quarantine restrictions on the Ukrainian economy). Shopping and leisure centres have also been considerably affected by the quarantine restrictions. Thus, according to the results of April-May 2020 they lost some $7 \mathrm{bln}$. UAH of lease revenue, while their lessees - over 50 bln. UAH of commodity turnover (source: The coronaviral nightmare for retail: how to survive in the storm).

Business, primarily small companies in the catering sector, suffered considerable losses in mid-November-beginning of December 2020 in the conditions of the so called "weekend quarantine". According to analysts' estimations (Siliveystr, 2020), Saturday and Sunday are the days when catering institutions get the main part of proceeds: over the weekend restaurants earn on average $41 \%$ of their weekly turnover, bars 
- 40\%, pizza houses and hookah lounges $35 \%$, fast food $-31 \%$, and confectioneries $30 \%$.

Critical situation of small and mediumsized companies puts the development of the middle class in the society at risk and reduces the development potential necessary to find a way out of the crisis. Restrictions in the activity of large companies constitute a source of threats for both budgetary safety of the state (due to reduced volume of taxes paid to the budget), and the threat to the currency safety (as the result of the loss of external sales markets and termination of currency proceeds supply to the country), which fact may have a negative impact on the stability of the national monetary unit in the future.

2.2.Social dimension. Reduced pace of macroeconomic development and economic mobility of economic entities in Ukraine as the result of the quarantine regime introduction due to the spread of the COVID19 pandemic have also had a negative impact on the social processes in the country.

$$
\text { As of mid-January 2021, }
$$
466.7 thousand people were officially unemployed in Ukraine, and out of them 106.6 thousand persons became unemployed over the quarantine period (March-December 2020) (source: Rating. Business in Official Figures). At the end of 2020 the rate of unemployment in the country made $9.5 \%$ to the respective-age workforce (at the end of $2019-\approx 8 \%$ ). The peak of unemployment growth fell on June-July, and the highest share of unemployed was traced in the trade and processing industries. And unemployment benefits over that period were paid only to some $83 \%$ of the unemployed.

In the coronacrisis conditions the State Employment Service got into the uncertainty regime: as the result of forced business inactivity planned revenues were going down, while the number of unemployed people who were getting registered was increasing (Zhalilo et al. (2020)).

Using the correlation and regression analysis, let us analyze the effect of specific factors of macroeconomic development and economic mobility of business entities (Table 2) on the increase in the unemployment rate in Ukraine.

Table 2. Input parameters for modeling the effect of factors on the unemployment rate growth in Ukraine

\begin{tabular}{ccc}
\hline Criterion & $\begin{array}{c}\text { Indicator name, } \\
\text { units of measurement }\end{array}$ & Parametres \\
\hline $\begin{array}{c}\text { Macroeconomic } \\
\text { development }\end{array}$ & Change in real GDP, \% to the respective quarter of the previous year & $x_{1}$ \\
& Export of goods and services, mln. USD & $x_{2}$ \\
Economic mobility & Share of unprofitable companies, \% to the overall number of companies & $x_{3}$ \\
of business entities & Volume of services sold to residents, mln. UAH & $x_{4}$ \\
\hline
\end{tabular}

Let us indicate that each of the above factors has been checked in terms of the possibility of its being used in the polynomial model as an independent variable. The degree of connection between each of the outlined factors and the unemployment rate was established through the pair correlation coefficient. All the coefficients of correlation between the unemployment rate and independent factors selected for analysis are significant, that is exert a direct impact on the unemployment dynamics.

The interaction of the resulting indicator (y) with factor characteristics $\left(x_{1}, x_{2} \ldots . x_{n}\right)$ is traditionally described through a linear multifactor regression equation. Using the fourfactor correlation and regression analysis we have built an economic and mathematical model that looks as follows:

$$
y=-8.714+0.038_{x_{1}}+0.002_{x_{2}}+0.139_{x_{3}}-0.0002_{x_{4}}
$$

High determination coefficient $\left(\mathrm{R}^{2}=0.833\right)$ proves availability of a considerable impact of the selected independent factors on the unemployment dynamics in Ukraine. 
Ranking of the factors included into the model by the degree of importance of their effect on the resulting indicator proves that the increase in the share of unprofitable companies has affected unemployment growth the most. This result is logical due to the fact that $\approx 83 \%$ of the Ukrainian population work as hired labour.

Unemployment growth in Ukraine has also been largely affected by the reduced real GDP growth rate. Other factors have had a less noticeable impact on the resulting indicator.

Reduction of the real GDP closely correlated with the reduction of the available population income $\left(\mathrm{R}^{2}=0.893\right)$.

The lion's share in the structure of the income of households in Ukraine is made up by salary. In spite of some reduction in the average monthly size in April and May (almost to the level of April-May 2019), in general its dynamics over 2020 was positive. However, in November in the dollar equivalent the above figure made 421.1 USD, which was $5.2 \%$ less than in the respective period of the previous year.

As compared to the beginning of the quarantine (March 2020), salary payment debt at economically active companies in December 2020 increased by $44.2 \%$ and made 2.7 bln. UAH compared with 2 bln. UAH in December of the previous year. The largest amounts of unpaid salary as of December 01, 2020 were recorded at industrial companies (primarily, machine-building ones as well as companies of the energy, metallurgy, and foodstuff industries), transportation companies, postal and courier companies, in the field of professional, scientific, and technical activity.

Thus, almost all the strata of the society had to reconsider the structure of their own expenses over the quarantine period, to reject many things that did not belong to "essentials", to reconsider their way of life. While residents of large cities reduced the costs of sports, entertainment, catering and services of the beauty industry, residents of small towns redistributed their costs in favour of purchasing foodstuffs, medicines, hygiene products and other essential goods (Zhalilo et al. (2020)).

One of the most negative consequences of the temporary termination of labour activity is underpayment of the unified social fee to the budgets of the Pension Fund of Ukraine, the Social Insurance Fund of Ukraine and the Fund of General Obligatory State Social Insurance in Ukraine ing Case of Unemployment. Thus, according to the data (source: Rating. Business in Official Figures), while in pre-crisis months, for example, in December 2019 and February 2020, the revenues from the unified social fee payments were, respectively, $28 \mathrm{bln}$. UAH and $23.5 \mathrm{bln}$. $\mathrm{UAH}$, in the quarantine months of April and May they went down, respectively, to 22.6 bln. UAH and 21 bln. UAH.

Along with that, according to the forecasts made by the National Bank of Ukraine, the volume of salary in 2021 will rise as compared to 2020 by $9.5 \%$, and the unemployment rate will make $8.6 \%$ of the respective-age work force (in the pre-crisis 2019 the respective figures were $9.7 \%$ and $8.2 \%$ ) (source: The National Bank of Ukraine).

In spite of the temporary purchasing power loss during the quarantine (particularly its rigid phase), uncertainty of the population both about short-term and long-term prospects caused a change in the population behaviour in relation to foreign currency purchase and sale. For example, in May 2020 the balance of currency exchange operations made $1.3 \mathrm{bln}$. $\mathrm{UAH}^{2}$, while in February it was -7.15 bln. UAH and in July - -6.07 bln. UAH (source: Rating. Business in Official Figures) (in the summer months this was partially caused by the vacation season). Expectation of the second wave of the quarantine in the background of the respective statements made by the Ukrainian authorities as well as expectation of the aggravation of the seasonal disease rate resulted in foreign currency

\footnotetext{
2 The negative value shows that residents have sold more currency than bought.
} 
purchasing by households. The balance of currency exchange operations in November made +3.59 bln. $\mathrm{UAH}$.

\section{Conclusion}

The above dynamic analysis confirms the research hypotheses suggested by the authors. The COVID-19 pandemic and rigid quarantine measures aimed to prevent its spread and reduce the morbidity rate drastically reduced macroeconomic development and business activity of business entities in Ukraine. As the result of the restrictions for business activity that were introduced, in particular, in the field of services, financial status of large and medium-sized companies deteriorated, and many small companies terminated their activity, which fact led to the dismissal of a part of staff as well as staying on forced leaves and reduced salary of those who were still employed, termination of investment projects implementation in most fields of regional economies. Limitation of population mobility, spatial breakdown of the relationship established between companies as well as between companies and clients caused reduced company profit and resident income, increased costs of arranging remote work places or delivery of the staff to the workplace for companies, reduced number of staff and increased unemployment rate, increased social tension.

In the conditions of poor control of the disease spread processes and uncertain timelines of the pandemic traditional measures for reducing the threats to economic security of the entrepreneurial sector seem to be inefficient: on the one hand, here is the crisis caused by the factors differing from traditional ones, and, on the other hand, here is a rapid fall in the financial and investment capacity of both the state and business, and households, which makes it impossible to widely apply tax, credit, investment mechanisms. In our opinion, the efficiency of the system of business activity stimulation in Ukraine can be secured through consideration of the effects of behavioural economy (in particular, irrational behaviour of households and business entities in the conditions of uncertainty, reduced efficiency of managerial decisions, information asymmetry) as well as direction of the limited financial resources into the domains of the country's economy that may ensure its smart specialization and/or build the capacity even in the pandemic conditions (e-commerce, online medicine, online education, IT, etc.). That will enable not just to overcome the risks caused by COVID-19 for business activity, but also to use the opportunities provided by the crisis for stimulating promising types of economic activity and restructuring the state economy.

\section{Acknowledgment}

The manuscript was prepared as part of the research topic «Globalization factors and risks of endogenous development of the regions of Ukraine» (performed by the Resolution of the Bureau of the Department of Economics of the National Academy of Sciences of Ukraine from 27.08.2020 № 7).

\section{References}

Andriy Pekhnyk, Yuliia Borzak (2020). The impact of the COVID-19 pandemic on the European economy: A first glance and long-term perspectives. The WSB University in Poznan. 90. 13-27. DOI: 10.26349/zn.wsb.w.poznaniu.0090.01.

Birbirenko S., Zhadanova Y., Banket N. (2020). Influence of pandemic of coronavirus infection COVID-19 on economic resilience of Ukrainian enterprises. Economic Annals-XXI: Volume 183, Issue 5-6.

Carlsson-Szlezak, P., Reeves, M., \& Swartz, P. (2020). What Coronavirus Could Mean for the Global Economy. Harvard Business Review, March 03, 2020. Retrieved from https://hbr.org/2020/03/what-coronavirus-couldmean-for-the-global-economy.

Chang, Chia-Lin, Michael McAleer, and Vicente Ramos. 2020. A charter for sustainable tourism after COVID-19. Sustainability 12: 3671 . 


\author{
Management Theory and Studies for Rural Business and Infrastructure Development \\ eISSN 2345-0355. 2021. Vol. 43. No. 3: 415-429 \\ Article DOI: https://doi.org/10.15544/mts.2021.38
}

Fiona X. Yang \& IpKin Anthony Wong (2020). The social crisis aftermath: tourist well-being during the COVID19 outbreak, Journal of Sustainable Tourism, DOI: 10.1080/09669582.2020.1843047.

Gössling, Stefan, Daniel Scott, and C. Michael Hall. 2020. Pandemics, tourism and global change: A rapid assessment of COVID-19. Journal of Sustainable Tourism 28: 1-20.

Ibn-Mohammed T., Mustapha K.B. etc. (2020). A critical analysis of the impacts of COVID-19 on the global economy and ecosystems and opportunities for circular economy strategies DOI:10.1016/j.resconrec.2020.105169.

Islam, Mohammed Rafiqul \& Muyeed, Abdul. (2020). IMPACTS OF COVID-19 PANDEMIC ON GLOBAL ECONOMY: A META-ANALYSIS APPROACH. International Journal of Technical Research \& Science. 05. 8-19. 10.30780/IJTRS.V05.I05.002.

Kulytskyi S. The problems of Ukraine's economic development, caused by the COVID-19 pandemic in the world and the search of ways to solve them.] http://www.nbuviap.gov.ua/index.php?option=com_content\&view=article\&id=4889:otsinka-perspektiv-rozvitkuukrajinskoji-ekonomiki-v-umovakh-pandemiji-covid-19\&catid=8\&Itemid=350 (date of address: January 2021).

Lenzen M, Li M, Malik A, Pomponi F, Sun Y-Y, Wiedmann T, et al. (2020). Global socio-economic losses and environmental gains from the Coronavirus pandemic. PLoS ONE 15(7): e0235654. DOI: 10.1371/journal.pone.0235654.

Liu, Jingxuan; Qiao, Ping; Ding, Jian; Hankinson, Luke; Harriman, Elodie H.; Schiller, Edward M.; Ramanauskaite, Ieva; Zhang, Haowei. 2020. Will the Aviation Industry Have a Bright Future after the COVID-19 Outbreak? Evidence from Chinese Airport Shipping Sector. J. Risk Financial Manag. 13, no. 11: $276 . \quad$ DOI: 10.3390/jrfm13110276.

Mukut Sikder, Wenzheng Zhang, Ujjal Ahmod (2020). The Consequential Impact of the Covid-19 Pandemic on Global Emerging Economy, American Journal of Economics, Vol. 10 No 6, pp. 325-331. DOI: 10.5923 / j.economics.20201006.02.

Official website of the State Statistics Service of Ukraine. URL: http://www.ukrstat.gov.ua/ (date of address: January 2021).

Pharma - the premier violin of the quarantine. Review of business trends. URL: https://youcontrol.com.ua/dataresearch/farma-persha-skrypka-karantynu-ohliad-trendiv-u-biznesi (date of address: January 2021).

Pro-Consulting: Retail during and after the quarantine. URL: https://commercialproperty.ua/interview/riteyl-pidchas-ta-pislya-karantinu/ (date of address: January 2021).

Rating. Business in Official Figures. https://q.rating.zone/ (date of address: January 2021).

Robert Dankiewicz, Bartłomiej Balawejder, Tomasz Tomczyk and Viktor Trynchuk (2021). The impact of the COVID-19 pandemic on the due payments of Polish entreprises from selected industries. Investment Management and Financial Innovations, 18(2), 144-154. doi:10.21511/imfi.18(2).2021.12

The average number of people falling ill per week in March-May varied from 9 to 474 (according to the data of Rating. Business in Official Figures. URL: https://q.rating.zone/) (date of address: January 2021).

The coronaviral nightmare for retail: how to survive in the storm. URL: https://www.unian.ua/economics/other/karantin-v-ukrajini-yak-perezhiti-koronavirusniy-zhah-riteylu-ostanni-novini11013341.html (date of address: January 2021).

The effect of COVID-19 and quarantine restrictions on the Ukrainian economy. Desk study, July 2020. URL: https://www.kas.de/documents/ (date of address: January 2021).

The effect of the crisis caused by the coronavirus pandemic will be felt until 2025.] URL: https://www.epravda.com.ua/news/2020/04/16/659487/ (date of address: January 2021).

The forecast of economic and social development of Ukraine for 2021-2023. Resolution of the Cabinet of Ministers of Ukraine as of July 29, 2020 No. 671 "On Approval of the Forecast of Economic and Social Development of Ukraine for 2021-2024”. URL: https://zakon.rada.gov.ua/laws/show/671-2020-\%D0\%BF\#Text (date of address: January 2021).

The Government has allowed distance selling of medicines. URL: https://www.slovoidilo.ua/2020/03/23/novyna/polityka/uryad-dozvolyv-dystanczijnyj-prodazh-likiv (date of address: January 2021).

The National Bank of Ukraine. Inflation Report, April 2020. URL: https://bank.gov.ua/monetary/report (date of address: January 2021).

The National Bank of Ukraine. Macroeconomic Forecast to the Inflation Report, October 2020. URL: https://bank.gov.ua/ua/news/all/inflyatsiyniy-zvit-jovten-2020-roku (date of address: January 2021).

Ukraine after the coronacrisis - ways of recovery: scientific suppl. / Ya. A. Zhalilo et al.; National Institute for Strategic Studies. - Kyiv: NISS, 2020. - 304 p.

Vahner I., Demko I. (2020). The effect of COVID-19 on the economic development of small and medium-sized business in Ukraine. Bulletin of the University of Banking. No. 1 (37). DOI: 10.18371/2221-755x1(37)2020208208.

Volodymyr Siliveystr. The quarantine of the weekend: bars and restaurants may find over $40 \%$ of their proceeds missing. URL: https://joinposter.com/post/karantin-vihodnogo-dnya-dlya-restoranov (date of address: January 2021). 